University of Nebraska - Lincoln

DigitalCommons@University of Nebraska - Lincoln

\title{
COMPETING CODES AND INVOLUNTARY CONFESSIONS OF THE FLESH IN LA PRINCESSE DE CLĖVES
}

\author{
Nora Martin Peterson \\ University of Nebraska-Lincoln, npeterson10@unl.edu
}

Follow this and additional works at: https://digitalcommons.unl.edu/modlangfrench

Peterson, Nora Martin, "COMPETING CODES AND INVOLUNTARY CONFESSIONS OF THE FLESH IN LA PRINCESSE DE CLĖVES" (2012). French Language and Literature Papers. 53.

https://digitalcommons.unl.edu/modlangfrench/53

This Article is brought to you for free and open access by the Modern Languages and Literatures, Department of at DigitalCommons@University of Nebraska - Lincoln. It has been accepted for inclusion in French Language and Literature Papers by an authorized administrator of DigitalCommons@University of Nebraska - Lincoln. 


\title{
COMPETING CODES AND INVOLUNTARY CONFESSIONS OF THE FLESH IN LA PRINCESSE DE CLÈVES
}

\begin{abstract}
L'ambition et la galanterie étaient l'âme de cette cour, et occupaient également les hommes et les femmes. Il y avait tant d'intêrets et tant de cabales différentes, et les dames y avaient tant de part que l'amour était toujours mêlé aux affaires et les affaires à l'amour. Personne n'était tranquille, ni indifférent; on songeait à s'élever, à plaire, à servir ou à nuire; on ne connaissait ni l'ennui, ni l'oisiveté, et on était toujours occupé des plaisirs ou des intrigues.
\end{abstract}

Ambition and gallantry were the sole occupation of the court, busying men and women alike. There were so many interests and so many different intrigues in which women took part that love was always mingled with politics, and politics with love. No one was calm or indifferent; everyone sought to rise, to please, to serve, or to injure; no one was weary or idle, every one was taken up with pleasure or intrigue.

-Madame de Lafayette, La Princesse de Clèves ${ }^{1}$

\begin{abstract}
$\mathrm{T}$ aken from the early pages of the Princesse de Clèves (1678), a text often referred to as the first modern French novel, the epigraph sets the stage for the delicate milieu into which the text's heroine is thrust a few pages later. It also raises questions about the nature of the courtly self: what it consists of, how it is constructed, and how it acts in public and private settings. Much of modern scholarship has sought to limn the origins of the early modern self, often locating it in seemingly paradoxical structures of power and knowledge such as sacramental confession. ${ }^{2}$ Addressing both religious and legal confessions in many historical contexts, Peter Brooks writes that it
\end{abstract}

1. Ed. Bernard Pingaud (Paris: Gallimard, 1972) 142. English edition: ed. John D. Lyons (New York: Norton, 1994) 10-11. All further references to the text are given parenthetically, with English translations appearing in the notes.

2. As famously argued by Michel Foucault in the first volume of his Histoire de la Sexualité (1976).

The Romanic Review Volume 103 Numbers 1-2 @ The Trustees of Columbia University 
is "deeply intricated with our sense of self, its interiority, its capacity for introspection, self-knowledge, self-evaluation" (171). In the Princesse de Clèves, confession, embedded this time in the courtly context, plays an undeniable, and yet complex, role in the unfolding of the main character's development. What I call involuntary confessions of the flesh-signs of the interior that slip out, unbidden, onto the exterior of the body - might appear to contradict the restraints of a century marked by René Descartes's privileging of the rational and by an increasingly strict imperative to rein in unruly signs of the flesh. ${ }^{3}$ In a court obsessed with appearance and dissimulation, how could involuntary confessions of the flesh possibly contribute to the development of the modern Western subject? I argue that such confessions strike to the very core of the early modern self. In the initial moment of their appearance, they cannot be performed, dissimulated, or falsified. ${ }^{4}$ Because of their intrusive and often

3. Claiming that one can attain "un empire très absolu sur toutes les passions, si on employait assez d'industrie à les dresser et à les conduire" (article 50), Descartes goes into detail about the passion of desire, which he identifies as the most violent, capable of rendering "toutes les parties du corps plus mobiles" (article 101). By the end of the seventeenth century, Descartes's treatment of the passions, especially as delineated in Les Passions de L'Ame (1649), had been extensively debated. Nicolas Malebranche (1638-1715), for example, writes that "Lorsqu'on est surpris de quelque passion violente, si l'on prend soin de faire réflexion sur ce que l'on sent dans les entrailles et dans les autres parties du corps . . comme aussi aux changements de visage qui l'accompagnent; et si on considère que toutes ces divers agitations de nerfs sont entièrement involontaires, et qu'elles arrivent même malgré toute la résistance que notre volonté y apporte, on n'aura grand'peine à se laisser persuader de la simple exposition que l'on vient de faire de tous ces rapport entre les nerfs" (RV II, I par. IV). Benedict Spinoza (1632-1677) disagrees even more strongly with Descartes in his Ethics, where he writes, "Man has no knowledge of himself except through the modifications of his own body and their ideas" (166). Jansenism, which gained momentum throughout the seventeenth century, emphasized the fallen nature of man and insisted that only God's grace could rescue man from this state of weakness. See Bénichou 122 for a complete description of the influence of this movement on thinkers and writers of the seventeenth century. In the Princesse de Clèves, readers see both systems of thought at work at once: the princess repeatedly tries to escape, mask, and overcome her passions, and she repeatedly fails in this Cartesian attempt to supersede her passions, thus also reflecting the Jansenist pessimism in the strength of the flesh. For more on the rhetorical treatment of passion and its influence on discourse, see Lamy.

4. Two examples from the text will shed light on the import of involuntary confessions. In the first, Mme de Chartres tries to convince her daughter that Nemours loves the dauphine instead of her. This makes the princess blush: "Elle fut si surprise de ce que lui dit sa mère, ... qu'elle changea de visage" (169). Then she withdraws from her mother's company, going on to reflect, by herself, on the significance of her reaction (169). The second comes soon after the princess confesses her inclination for another 
unwelcome effect, they must quickly be deciphered and incorporated into an acceptable mode of discourse, or else they threaten to destroy the exterior facade of courtliness so carefully established. Nevertheless, moments in which systems of control break down, oscillations between public and private attempts to stay in control, and representations of the body under emotional stress, though indeed troubling, are all integral parts in the machine of early modern self-production, as they give readers a place to begin to look for the self. In the pages that follow, I focus on moments that interrupt the civilizing process, arguing that these seemingly destructive shows of the interior are, in fact, equally, if not more, invested in the production of the self as the layers of dissimulation involved in the proper behavior demanded at court. The relationship between involuntary confessions of the flesh and dissimulative behavior, as highlighted by the tension between theoretical models of confession and restraint, shows the extent to which the princess's interior is deeply troubled. ${ }^{5}$ As Brooks writes, "confession ... both creates and is created by a new sense of selfhood" (97). Involuntary confessions of the flesh arbitrate between confession and dissimulation, creating an ultimately productive tension. Rather than argue for the triumph of interiority in the Princesse de Clèves, I show that conflicting codes impede conclusive development. Nevertheless, involuntary confessions of the flesh grant the reader access to the princess's nascent, albeit troubled, interior, in ways that no verbal confession or dissimulative performance ever could.

In an act that she, her husband, members of court, and the author herself all proclaim to be matchless, the princess confesses to her husband that she has developed feelings for another man. Rather than succumbing to these feelings, she begs him to take her away from court. At the end of the text, again explicitly pointing out the rarity of her candor, the princess divulges her true feelings to $M$. de Nemours, the object of her affection, and then goes on to explain why she will not fulfill them. Both her first confession, or aveu, (to her husband) and her second (to Nemours) mark central moments in the princess's development; more importantly, they highlight how deliberately she seeks to

to her husband but refusés to reveal his identity: "Le nom de M. de Nemours et la pensée d'être exposée à le voir tous les jours, pendant un long voyage, en présence de son mari, donna un tel trouble à Mme de Clèves qu'elle ne le put cacher" (249). Both instances highlight the revelatory power of involuntary confessions of the flesh-in the first, to the blusher herself, and in the second, to the one witnessing the confession. 5. My use of the term dissimulation here and throughout refers to its highly complex usage and role in determining social success during the seventeenth century. I am particularly interested in the way it reflects the Italian concept of sprezzatura (the art of appearing artless). See below for a more in-depth analysis of this concept in Madame de Lafayette's text. 
carve out an interior space for herself. ${ }^{6}$ The moments in which the princess loses control of herself teach her (and the reader) as much about her interior as do those in which she attempts to navigate court culture.

\section{The Competing Codes of the Bête d'Aveu and the Bête Courtoise}

For Michel Foucault, the imperative that all Christians attend confession annually is a central moment in the development of the modern Western self. ${ }^{7}$ He examines the relationship between power and knowledge, a combination that, he claims, results in the production of truth: "Depuis le Moyen Age au moins, les sociétés occidentales ont placé l'aveu parmi les rituels majeurs dont on attend la production de vérité ... on avoue, ou on est forcé d'avouer. Quand il n'est pas spontané, ou imposé par quelque impératif intérieur, l'aveu est extroqué; on le débusque dans l'âme ou on l'arrache au corps" $(78,79) .{ }^{8}$ Along the same line of thought, Brooks writes that "confessional literature gives the impression of depth and recess, delving into the subject's past and into the subject's deepest and most hidden thoughts and wishes, in order to account for the individual self" (102). Whereas involuntary confessions of the flesh are obviously not produced in the same way as their verbal counterparts, they reflect the same kind of depth. The violence with which they wrest themselves to the body's surface is indicative of a similar kind of production of truth. As a result of confession, the individual gradually becomes increasingly "responsible for the discourse of his or her own identity and personal-

6. However, it is equally important to note the differences between the two. In the first confession, the princess does not reveal who-or even, explicitly, that-she loves, but in the second instance, she openly admits her feelings, at least verbally. Later in the text, Monsieur de Clèves tricks his wife into confessing (to his satisfaction) her preference for Nemours by pretending that he will accompany them on their journey with the king; the princess's blush at the sound of Nemours's name gives her away in her husband's eyes (249). Finally, it is important to note that readers do not have access to the aveu she makes to her husband, whereas they are admitted to the second confession. All of these pieces of parallel and contrary evidence underscore the complexity of the confessional systems, some of which are nonverbal, at work simultaneously in the text. They also indicate a trajectory of confessional development that culminates with her second aveu; this point will be examined in greater depth below.

7. As mandated by the Fourth Lateran Council (1215).

8. "Since the Middle Ages at least, Western societies have established the confession as one of the main rituals we rely on for the production of truth.... One confesses-or is forced to confess. When it is not spontaneous or dictated by some internal imperative, the confession is wrung from a person by violence of threat; it is driven from its hiding place in the soul, or extracted from the body" $(58,59)$. 
ity" (110). Much as in a verbal confession, the producer of an involuntary confession of the flesh has a moment in which to allocate, hide, or interpret her slip before it is subjected to the scrutiny of onlookers. ${ }^{9}$ It is here that the realms of confession and restraint overlap. Foucault is not wrong to write that "l'individu s'est longtemps authentifié par la référence des autres ... puis on l'a authentifié par le discours de vérité qu'il était capable ou obligé de tenir sur lui-même" (78-79), but he is imprecise. ${ }^{10}$ It would be more accurate to say that during the seventeenth century, both of these discourses occurred simultaneously. In the Princesse de Clèves, members of court still define themselves largely by reference to others, even as the secular confession at work in the text produces strains of truth that operate very much in accordance with the Foucauldian model. ${ }^{11}$ If Foucault describes the modern Western subject as a bête d'aveu, then it coexists in the Princesse de Clèves with what I would call the bête courtoise. The drive to dissimulate at all costs stands in direct contrast with the impetus to confess. These two modes of reading and producing meaning stand in an uneasy negotiation with each other, making the significance of involuntary confessions of the flesh even greater. While these confessions illuminate similar truths as verbal confessions, and despite that (or perhaps because) they often arise in reaction to the restraints imposed on members of court, they are completely organic. The moments in which involuntary confessions slip between both discourses are the moments in which they are at their most productive. Where does this leave the princess in the wake of her singular confession? As a woman in search of her own identity apart from court, she

9. To verbal and nonverbal confessions, and to the tension between the modes of dissimulation and confession, one must also add the complexity of the meaning of the verb avouer in the seventeenth century. In "Lafayette's Ellipses," Joan DeJean explores the seventeenth-century usage of the term avouer, which Madame de Lafayette consistently favors over confesser (most English translations, however, prefer confession). Avouer began to be used in the sense of legal confession of crimes in the mid-seventeenth century. However, DeJean points out that the princess takes care to emphasize her innocence, enacting instead "an aveu in the earlier legal sense of a loyalty oath" (896). I would add that Monsieur de Clèves's trick to make her nonverbally confess her preference for Nemours (see n. 6 above) complicates the legal meaning of avouer in the legal sense; the two instances and meanings complexify each other much in the same sense that both meanings of the word come into play in the seventeenth century.

10. "For a long time, the individual was vouched for by the reference of others ... then he was authenticated by the discourse of truth he was able or obliged to pronounce concerning himself" (58).

11. Exemplified, for instance, in the large amount of contextual information at the beginning of the text, the numerous embedded narratives, and the perpetual operation of courtly behavior. 
unwittingly gets stuck between what Foucault calls a "codification clinique du 'faire parler"' $(87)^{12}$ when she confesses to her husband and the realization that to remain virtuous, she must simultaneously conceal her true feelings.

In The Civilizing Process (1939), a groundbreaking sociological investigation of early modern manners and personality since the late Middle Ages, Norbert Elias writes that in the Renaissance, "society was in transition. . . People saw things with more differentiation, i.e., with a stronger restraint of their emotions" $(61) \cdot{ }^{13}$ The term civilité emerged simultaneously with the move toward "civilization," entering into the vocabulary of manners in France during the sixteenth century together with several influential conduct manuals. ${ }^{14}$ Inspired by Baldassare Castiglione's Book of the Courtier (1528), court society placed an increasing demand on self-control, dissimulation, and courtliness. ${ }^{15}$ In France, and closer to the world of Madame de Lafayette, Nicolas Faret's L'honneste homme, ou, L'art de plaire à la court (1630) further insisted on concealing the passions:

Il y a de mesme une reigle generale qui sert sinon à lacquerir, du moins à ne s'en esloigner jamais. C'est de fuyr comme un precipice mortel cette malheureuse et importune Affectation . . . et d'user par tout d'une certaine negligence qui cache l'artifice, et tesmoigne que l'on ne faut rien que comme sans y penser, et sans aucune sorte de peine. ... Soyons donc maistres de nous-mesmes, et sçachons commander à nos propres affections, si nous desirons gaigner celles d'autruy. $(34-35,165)^{16}$

12. "clinical codification of the inducement to speak" (65).

13. For a thorough investigation of Elias's work, see Jonathan Fletcher, Violence and Civilization: An Introduction to the Work of Norbert Elias (Cambridge: Polity, 1997); Stephen Mennell, Norbert Elias: An Introduction (Dublin: U College Dublin P, 1998); and Robert van Krieken, Norbert Elias (New York: Routledge, 1998).

14. The first of these to make waves across Europe was Desiderius Erasmus's De civilitate morum puerilium (On civility in boys) (1530).

15. Although Castiglione's text was arguably the most influential, I do not mean to imply that court manuals remained static from his text on. Treatises, while borrowing heavily from the tenets set forth by Castiglione, reflected the rulers and modes of the respective courts at which they were written. For my purposes, I distill those passages about affect that appear to remain relevant in the Princesse de Clèves. For more about the sociopolitical sphere of conduct manuals, see Jorge Arditi, A Genealogy of Manners: Transformations of Social Relations in France and England from the Fourteenth to the Eighteenth Century (Chicago: U of Chicago P, 1998), especially 122-54.

16. "There is a general Rule ... [a]nd that is to avoid AFFECTATION with all imaginable Care ... and upon every Occasion to act in such a certain negligent Manner, as shall conceal Art, and testify that we do all things, as it were, by Inspiration. . . . Let 
The focus on overcoming one's passions reflects in part the influence of Cartesian thought on seventeenth-century society as well as an increasingly centralized sense of power at court. Courtly "authenticity" is not based in internal truth but in the truth one hopes to perform. By implying that he is what he seems, and seems what he is, the successful courtier embodies bienséance. ${ }^{17}$ The text does not even pretend to advocate the true acquisition of virtuous behaviors and opinions, but skips to the semblance of them.

The workings of early modern society, Elias writes, are deeply entrenched with this move toward courtliness: "The web of actions grows so complex and extensive, the effort required to behave correctly within it becomes so great, that beside the individual's conscious self-control an automatic, blindly functioning apparatus of self-control is firmly established" (Court 367-68). Elias's claim is that sixteenth-century aristocrats are conditioned from an early age to react instantaneously and instinctively to outside stimuli. In fact, he writes, by the time the court society reaches its zenith late during the reign of Louis XIV and into the rule of Louis XVI, "Etiquette was borne unwillingly, but it could not be breached from within, not only because the king demanded its preservation, but because the social existence of the people enmeshed in it was itself bound to it" (Court 87). Members of court lived with an increasing tension between the self and the civilizing process, and there was a growing awareness of the difference between the self and the courtly game it is asked to participate in. ${ }^{18}$

us then be Masters of ourselves, and learn to control our own Affections, if we desire to gain those of others" $(17-18,78)$. Other influential manuals in seventeenth-century France include de Chalesme, L'Homme de qualité, ou les moyens de vivre en homme de bien et en homme du monde (1671); the three treatises by the Chevalier de Méré (Des Agrémens, de l'Esprit, and de la Conversation [1677]); Antoine de Courtin, Nouveau traité de la civilité qui se pratique en France parmi les bonnêtes gens (1671); and Charles Sorel, Les Lois de la galanterie (1644). I am indebted to Lewis C. Seifert, whose book Manning the Margins: Masculinity and Writing in Seventeenth-Century France (Ann Arbor: U of Michigan P, 2009) takes up the question of galanterie from the perspective of masculinity.

17. Although I am arguing that involuntary confessions of the flesh appear despite and in contrast to the rules set forth by the civilizing process, it must be acknowledged that, in some cases, truth and appearance of truth do and can coincide. The possibility that an individual has so completely assimilated the rules of the game is legitimate; however, this standpoint endows the "game" with all of the credit and provides more insight into the structures of power at work than into the development of the individual.

18. See, for example, the Maximes of La Rochefoucauld (1st ed. 1665) and also C. Clark, La Rochefoucauld and the Language of Unmasking in Seventeenth-Century France (Geneva: Droz, 1994). 
At the outset of the text, the young princess, who has not been exposed to courtly stimuli, is quite inexperienced when it comes to discerning any kind of truth from this complex web of dissimulation. Before the princess and Clèves marry, Lafayette draws our attention to a blush that functions as a marker of social currency. When her fiancé complains that she does not love him as she should, the princess attempts to infuse her blushing with the meaning she hopes to convey: "Je rougis si souvent en vous voyant que vous ne sauriez douter aussi que votre vue ne me donne du trouble.'-'Je ne me trompe pas à votre rougeur,' répondit-il; 'c'est un sentiment de modestie, et non pas un mouvement de votre Coeur, et je n'en tire que l'avantage que j'en dois tirer.' Mlle de Chartres ne savait que répondre, et ces distinctions étaient au-dessus de ses connaissances" (150; emphasis mine). ${ }^{19}$ Both Clèves and the princess refer to the blush as a cultural sign, essentially drawing the distinction between the modest and shameful blush. Because the princess has only just arrived at court, and because she has not yet learned the language of court, she believes she is giving Clèves the proof of affection he seeks. ${ }^{20}$ Instead, he recognizes that her blushes point to modesty rather than to any kind of desire for him. The princess is soon thereafter admonished by her mother, "Si vous jugez sur les apparences en ce lieu-ci ... vous serez souvent trompée: ce qui paraît n'est presque jamais la vérité" (157). ${ }^{21}$ By the time the princess "hopes to show no sign of her love" for Nemours, she has learned the difference between the two kinds of blushes. All subsequent blushes in the text point to her feelings for Nemours rather than her virtuous respect for her husband.

Despite having learned her lesson well, the princess still seeks to retain distance from the court's intrigues. Elias writes that courtly women experienced an increase in "the inner constraint, the self-control which she had to impose on herself in accordance with the form of integration and the code of behavior of court society" (Civilizing Process 156). The same is not unequivocally true of the princess; while our young heroine does seek self-mastery, she does not seek it unconditionally. At least initially, the princess seeks to overcome the courtly codes and achieve true virtue. Rather than behave correctly in the sight

19. "II blush so often when I . . see you that you may be sure that the sight of you affects me.' 'I am not deceived by your blushes,' he urged; 'they come from modesty, and not from any thrill of your heart, and I do not exaggerate their importance.' Mademoiselle de Chartres did not know what to answer; these distinctions were outside of her experience" (15; emphasis mine).

20. Thomas DiPiero identifies the princess's struggles as an "inability to reproduce court discourse and appearances in convincing fashion" and argues that this fault stems in part from her lack of experience there (206).

21. "If you judge from appearances here ... you will be often mistaken; what appears is seldom the truth" (19). 
of others, she seeks to behave correctly in the sight of herself. But it is not so simple, for by moving within the sphere of the court, she gets caught up in the wheel of the civilizing process as well as in the intrigues of courtliness. This is problematic for many reasons, since in the moment she falls in love with Nemours, the princess can no longer separate herself from the frenzied signmaking that she hopes will throw Nemours and other members of the court off track. The game of love, as Elias writes, "is influenced not only by their half-involuntary, half-voluntary affect-masking itself, but also by awareness of the masks, by reflection on them" (Court 258). Catherine Liu refers to a central passage in the text, cited at the beginning of this article, pointing out that "Lafayette's heroine is torn between the aggressive desire to distinguish herself . . . and the civilizing imperative (bienséance) to suppress all marks of particularity or sentiment. The tensions that traverse the subject of such a civilizing process are represented in the narrative of the novel: [it] becomes the site of their representability" (134). ${ }^{22}$ The princess's involuntary confessions of the flesh embody the gap between showing and telling, between trying not to show and trying to tell things in a certain way. Whether or not she is aware of it, the princess's dissimulations transform her into a participant in the courtly game of courtliness.

Once the princess learns 'that the 'real' is what one is able to make others believe and recognize as the truth" (Alliston 55), she gains a great advantage in her self-making project. As she observes herself, knowing that others' eyes are on her, she learns what it means to behave according to the code and what the likely reaction will be if one acts against it. ${ }^{23}$

The princess is representing herself to others, but she is also representing herself to herself, since she is here capable of discerning appropriate from inappropriate courtly behavior, distinctions that were previously "au-dessus de ses connaissance" $(150) .{ }^{24}$ Even if she does not successfully convince Clèves

22. Anna Bryson documents how the early modern body was a frequent site of "tension, conflict, and negotiation" (25).

23. For example, when Clèves attempts to discern the identity of the one for whom his wife bears affections, she blushes, then threatens, "si vous essayez de les élaircir en m'observant, vous me donnerez un embarrass qui paraîtra aux yeux de tous le monde" ["if you try to find out by watching me, you will surely make me so embarrassed that every one will notice it"] (248; trans. 70). Her blush at the beginning of the passage highlights her lack of control over her feelings for Nemours, but she uses the threat of a future, public loss of control in order to keep her husband from manipulating her. The princess is familiar enough with the code to know what will likely happen if she blunders in public.

24. For a more detailed discussion of the relationship between the "authentic" and the self, see Berger 299. 
that her blush is a blush of shame, there are certainly several other moments when her slips fit into the standards put forth by courtly norms.

Quoting from Jean de la Bruyère (1645-1696), another influential French specialist on conduct roughly contemporary with the Princesse de Clèves, Elias uses early modern vocabulary to explain the increasingly mechanical process of dissimulation: "Each man, as it were, confronts himself. $\mathrm{He}$ 'conceals his passions,' 'disavows his heart,' 'acts against his feelings'" (Civilizing Process 399). For Elias, adherence to codes of civilized behavior becomes almost synonymous with self-identification. The representation of the self becomes more important than the actual self. At the very least, every attempt at dissimulation effectively and increasingly blurs the boundary between self and representation.

The complex new system of rules, which materializes during a time when so much of individual identity is on the cusp of falling into place, highlights both the vulnerability and the fertility of the early modern self. If Elias believes that the civilizing process at court contributed to early modern self-making, others highlight the distractions inherent in courtly behavior. In Before Imagination, John D. Lyons articulates the obsession with sign-making as a replacement for "training [the] imaginative faculty in a selective way." Rather than focusing on the creation of self, the early modern members of court devoted most of their energy to the production of signs, since, in their view, "they perceive the world as a set of signs and the people in it as producers and receivers of signs" (166). ${ }^{25}$ The disconnect between those scholars who argue that the restraints of the civilizing process led to a greater sense of self-identification and those who believe that the culture of dissimulation created nothing more than a mirage of signs and representations need not be resolved here. What I mean to show is that the civilizing process proposed by Elias brought about a drive toward self-control but simultaneously resulted in the opposite, with the imperative to confess. If the Foucauldian description of confessional discourse is the theorization of the self, then the civilizing process is its antitheorization. By restraining what one can say or do, the self cages itself within a narrow sphere of possibility. In the world of the Princesse de Clèves, both discourses must coexist; the princess chooses to confess to her husband at the same time as she tries to restrain herself externally. She resists giving in to her feelings for Nemours, thus excluding herself from the courtly game, but she relies on courtly mechanisms in order to achieve her noncourtly goal. The two ostensibly opposite motions-one toward disclosure, one toward concealment and

25. See also Bryson, who writes that codifications and behavior manuals "tell us how we ought to feel and think, rather than being a direct description of what we do, in fact, think and feel ... there is a gap between experience and articulable norms" (12). 
dissimulation-are never fully resolved. ${ }^{26}$ The tension between confession and dissimulation can be better parsed in the context of another important early modern courtly subtext-that of sprezzatura.

\section{Sprezzatura, or the Art of Appearing Artless}

In Castiglione's Book of the Courtier, Count Ludovico reveals a new principle by which he claims to "avoid affectation in every way possible as though it were some very rough and dangerous reef" $(1.26) .{ }^{27} \mathrm{He}$ calls it the code of sprezzatura and glosses it as the capacity to "conceal all art and make whatever is done or said appear to be without effort and almost without any thought about it" (1.26). It is, as Harry Berger expounds, "an art that hides art, the cultivated ability to display artful artlessness . . the ability to show

26. The most obvious exception is the reverie scene at Coulommniers. Separated from her husband and seemingly alone (although she is being secretly watched by Nemours), the princess wraps Nemours's colors around a cane, presumably lost in thought about him as she gazes at his portrait (281). This scene appears to be a voluntary confession as well as evidence of a well-developed interiority. My reasons for not extensively commenting on this example are twofold. First, it has been exhaustively commented on by other scholars. Some of the most important of these commentaries include the contributions of Nancy K. Miller (15-38), Joan DeJean (39-70), Donna Kuizenga (71-86), Patrick Henry (156-180), Marie-Odile Sweetser (209-224), and Philippe Desan (104-126) in An Inimitable Example: The Case for the Princesse de Clèves, ed. Patrick Henry (Washington, DC: Catholic U of America P, 1992). However, I believe that the intellectual focus on this particular episode disadvantages other moments and other forms of confession in the text, some of which I highlight in my own analysis. The reverie is indeed a moment in which the princess confesses, to herself and to her reader, the depth of her feelings in a natural setting, free (or so she thinks) from the eyes and judgment of court. However, what I wish to highlight is the extent to which this one example has come to symbolize the princess's interior development, despite the fact that her own identity is tied up in courtly education. The reason the princess comes to court in the first place is to receive a different kind of education than she received alone with her mother. Because her identity is carefully, purposefully, and inextricably woven into the impetus to confess everything (to her mother, then her husband) and the exhortation to follow the code of courtly behavior, the princess cannot be judged alone by this scene. Nor can she be judged alone. As if to prove this point, Lafayette gives the reverie an audience. Not only the readers but also Nemours are present to observe the princess. By analyzing her behavior and adding depth to the force of her feelings during this scene, outside viewers-including scholars and critics-are perpetuating the game of reading and evaluating.

27. Other important manuals, though by no means exhaustive, include Thomas Wright, The Passions of the Minde (1601); S. R., The Courte of Civill Courtesie (1582); and Thomas Dekker, The Gull's Hornbook (1609). 
that one is not showing all the effort one obviously put into learning how to show that one is not showing effort" $(295-96) .{ }^{28}$ For the princess, then, as Henri Coulet writes in Le Roman jusqu'à la revolution, "la bienséance n'interdit Madame de Clèves d'aimer Nemours, elle lui interdit seulement de le montrer!" (259). ${ }^{29}$ Though in her debut at court the princess presents herself as a girl bent on remaining virtuous, she decides at a certain point that she must give up her hope of renouncing her love for Nemours: "Elle ne se flatta plus de l'espérance de ne le pas aimer; elle songea seulement à ne lui en donner jamais aucune marque" (194). ${ }^{30}$

Rather than refuse to play the game of courtliness, as many critics have suggested, the princess realizes the need to play according to the rules if she is to succeed in distinguishing herself. Sprezzatura fulfills her need to conceal at the same time as its frenzy to produce signs makes any kind of interpretation difficult. In Renaissance Self-Fashioning, Stephen Greenblatt suggests that "the single self ... is a rhetorical construct designed to enhance the speaker's power, allay his fear, disguise his need" (141). Once the princess learns that nothing around her is as it seems, she becomes increasingly interested in not seeming what she is. She devotes much of her energy to hiding her true feelings for Nemours in public. ${ }^{31}$ The obsession with presenting herself in a certain way corresponds to Elias's study of courtly restraints, but it also reflects a more general crux of early modern thought. ${ }^{32}$ Members of elite society "are acutely

28. See Wayne Rebhorn's comprehensive study, which goes into much greater depth than is possible here: Courtly Performance: Masking and Festivity in Castiglione's Book of the Courtier (Detroit: Wayne State UP, 1978), especially $38 \mathrm{ff}$. See also John D. Lyons, "Narrative, Interpretation, and Paradox: La Princesse de Clèves," Romanic Review 72 (1981): 383-400.

29. "The court does not forbid Madame de Clèves from loving Nemours; it forbids her only from showing her love" (259). This changes after Monsieur de Clèves's death; henceforth, nothing forbids the princess from showing her love for Nemours. That she continues to withhold her consent to a relationship indicates that she does not come to fully operate within the context of sprezzatura. Instead, she continues to split herself between the two models of dissimulation and a duty to a self that supersedes the masks of sprezzatura even as it participates in the masking.

30. "She did not longer indulge in the hope of not loving [Nemours]; she merely determined to give him no further sign of it" $(40)$.

31. When she does confess, it is when she believes her actions will not be easily discerned by others. The two most notable cases include the case of the tournament and during the reverie. These, however, are voluntary confessions that reveal more about her way of expressing something she already knows about herself, and not involuntary confessions, which appear spontaneously and which teach the princess something about herself she would not otherwise have had access to.

32. Bates identifies the dissimulative nature of court culture with the New Historicist fascination with the public sphere (351). 
aware of what might be called 'identification' in a broader sense: the tendency to attach what is outside the self to one's own self-image" (Moriarty 24). The early modern self cannot exist without an audience to judge its performance. But what kind of interiority depends on exposure? How can the self make itself into something independent when its existence depends on successful outward projection? ${ }^{33}$

The kind of self-fashioning posited by Greenblatt and others shares certain characteristics with involuntary confessions of the flesh. Harvesting any kind of knowledge from an involuntary confession depends on exposure-such confessions are triggered by an audience (for who would ever blush alone?)and they result in (positive or negative) judgment. Thus involuntary confessions of the flesh participate both in the confessional discourse and in the game of sprezzatura at court. Only by exposing oneself to the judgmental public can an individual exteriorize what hides within. Paradoxically, this is exactly what individuals hope not to do. In a world of dissimulation, the threat of exposure "made [people] more aware of how reputations could be produced and appearances maintained. ... The art which concealed art was exposed for the world to see" (Bates 355 ). ${ }^{34}$ An implicit understanding among welleducated members of court revealed an awareness of the performative selves with which they engaged. Seemingly a contradiction, self-fashioning at court demanded constant self-control, the result of which was self-estrangement (not self-knowledge). ${ }^{35}$ The princess must constantly be aware of her own presentation; to hide her true feelings, she must be cognizant of what they are. Acknowledging that everything and everyone is only the semblance of a rhetorical construct of self might appear pessimistic, but it forces an intimate appreciation of what kind of self to present to the world.

At certain moments, the princess confesses her true feelings-willingly, as in the case of the reverie at Coulommiers (during which she is actually being observed), or unwillingly, as after reading the letter she thinks to be written by Nemours (at which point she must account for the consequences of the jealousy she involuntarily acknowledges). In these two examples, in particular, the reader sees the heroine of the text coming to terms with her own singularity but simultaneously recognizing her need to uphold either the mode of confession or the mode of dissimulation or both. She cannot break free completely; she recognizes her options and continually tries to break free from both modes. By repeatedly stressing her singularity, she insists on being

\section{See Marin.}

34. Drawing the connection between the milieu of the court and the structure of the text itself, Stephanie Merrim writes that "both court and text revolve around appearances versus reality, deceptions versus disillusionments" (97).

35. See Greenblatt 31. 
judged differently. Still, she engages in dissimulation throughout the text, and her voluntary confessions are, although singular, still the products of premeditated self-representation. The true place to look for the princess's interior, if one wishes to truly separate her from her self-presentation, is in the confessions she makes involuntarily, the moments in which she interrupts her public self-making quest. The spontaneous outbursts do not belong to the masking procedures (although they are often integrated into a system of reading), and they are unavoidable marks of truth in an otherwise unstable world of signs, rhetorical constructions, and observed confessions. ${ }^{36}$

Why would the princess come to care so much about matching her behavior to a code of legibility, when she previously sought to avoid the web of gallantry? Joan DeJean explains that although the princess is desperately trying to eke out an identity, it must stand up to courtly scrutiny. She must constantly "pretend to look one way while looking in another in an attempt to glimpse the truth camouflaged by a façade of codified behavior" (891-92). What kind of interiority can exist when truth is something that can be produced, and when the self is already tied up in questions of performance and presentation? Catherine Bates sheds light on the extent to which representation and self are inextricable in early modern court culture. Handbooks, she writes, are

nothing less than a detailed programme of their production, laying down exactly how the appearance of courtliness is rhetorically to be constructed and maintained. Courtliness depends ... on the effectiveness of the representation, on the ability to persuade, to master the art of rhetoric. It depends on the consistency and plausibility of the surface narrative... . The court is relentlessly shown to be a literary construction-actively produced with words.... the court does not exist except in such representations. (350)

My point in insisting on the artificiality represented in these conduct books is to show that in a court that depends wholly on maintaining appearances, and in which identity is tied to the attempt to appear favorably, it is difficult to keep track of the truth of the self. It is difficult to know that one is acting one way but thinking and feeling another, and that one must pay attention to both if one is to simultaneously cultivate a good reputation as well as succeed in society. What happens when readings of the body are increasingly "antitheorized," that is, when they are more interested in representing than in truth

36. Louise K. Horowitz writes that "the body announces exactly what the mind seeks to obliterate. The mark of erotic passion is the complete inability to disguise it, and the spontaneous expression of this passion-unnatural silences, blushes, self-conscious gestures-is the surest sign of the mind's loss of control" (58). 
telling? Conduct manuals and their multiplicity of readings and behavioral prescriptions make up a self-consciously overdetermined genre. Therefore one must depend on other signs, such as involuntary confessions themselves, for more information about the self-making process. More than sprezzatura, involuntary confessions provide important insights into reactions and reflections. By trying to prevent slips, the princess learns about the situations that cause her to slip. When she does slip, she gleans some truth about herself; at the same time, she must figure out how to inscribe the slip into the civilizing process.

\section{Reading the Princess}

Although involuntary confessions of the flesh most commonly take place in public, this does not mean that they are always noticed. In a good many situations, the princess blushes or otherwise slips in public, but Lafayette explicitly points out that no one was paying attention. By emphasizing that the princess gets away with her slip, the author draws the reader's attention: "Si elle n'eût point été dans l'obscurité, elle eût eu peine à cacher son trouble et son étonnement de voir entrer M. de Nemours conduit par son mari" (228). ${ }^{37} \mathrm{Or}$, in another case, "Mme de Clèves se mit à genoux devant son lit et, par bonheur pour elle, elle n'avait pas le jour au visage" (253). ${ }^{38}$

The princess slips silently, revealing only to the reader that she feels both embarrassment and shame. Silent slips provide a metatextual alternative to the codified interpretations one might find in the handbooks. Since no one notices her trouble, her slips are not codifiable, but readers can easily discern the truth behind her discretion. The princess's secret involuntary confessions provide readers with emotional feedback about her true feelings at the same time as they supersede the civilizing process. ${ }^{39}$ Lafayette's decision to give readers access to these slips indicates that involuntary confessions of the flesh provide more useful feedback about the self than any other kind. ${ }^{40}$ They mediate between the competing voices of truth and antitruth. If the body serves as the battleground between civilizing process and confession, then involuntary confessions of the flesh are the weapons used by each side.

37. "Nothing but the darkness enabled her to hide her agitation and surprise at seeing Monsieur de Nemours brought into her room by her husband" (59).

38. "Madame de Clèves knelt down by the side of the bed in such a way that, fortunately for her, her face was in the dark" (73).

39. Inge Crosman Wimmers believes that such moments allow the reader to "follow each step of her reasoning and to fully share the emotional impact" (50).

40 . One might remember, by way of contrast, that readers do not have access to the words of the princess's confession to her husband. 
The incorporation of sprezzatura into her actions signals a shift in the princess's education and in her view of how to best function in court culture. Involuntary confessions provide insight into her moments of exposure-they show readers that she is not only participating in the game of sign-making but also generating her own opinions and feelings about the options available to her. By giving the reader full access to even her most secret involuntary confessions, Lafayette intentionally carves out a path of internal development for her young heroine, thus turning away from, rather than relying on, the precepts of seventeenth-century society.

The princess's passion for Nemours culminates in a final showdown-after privileging sprezzatura over confession for much of the second half of the text, the princess decides to remove several of her masks and revert to verbal honesty, confessing her true feelings to Nemours himself. One might think twice, however, before concluding that the self underneath these masks is a clearly defined, deliberate interior. First of all, the scene of the confession to Nemours in many ways mirrors the earlier confession to her husband. The princess begins by insisting on the singularity of her impending words: "Je [vous parlerai] avec une sincérité que vous trouverez malaisément dans les personnes de mon sexe... [c] sera apparemment la seule fois de ma vie que je me donnerai la liberté de vous les [sentiments] faire paraître" $(301,305-6) .^{41}$ The princess indicates that she is confessing her true feelings for Nemours freely, but qualifies her liberty by stating her resolve never to appear thus before him again. ${ }^{42}$ The passage is marked by various involuntary confessions of the flesh.

41. "I will speak, with a frankness that you will not always find in women. . . this probably will be the only time in my life that I shall take the liberty of letting you see them [my feelings]" $(101,103)$.

42. As in the first aveu, it is important to note the emphasis on gender here; Lafayette stresses that no other woman has made such a statement. The problems of gender become thicker when one considers that courtly manuals were constructed largely for and by men; in such cases in which advice on decoding women's signs of the body is given, it is a matter of men reading women. Unfortunately, I do not have the space here to fully consider the implications of gendered confessions of the flesh, nor is my argument an inherently gendered one. However, excellent work has already been done to discuss the princess's actions (or inactions) throughout, and especially at the end of, the text from an explicitly feminine perspective. Faith Beasley has written that Lafayette "creates a complex dialectic between the historical 'background' and the fiction to make her heroine's actions plausible within the economy of the text, thus proposing an alternative to her society's concept of plausible female behavior" (196). Nancy K. Miller focuses on the reverie scene at Coulommiers as the princess's most gendered statement of desire (42ff), and Joan DeJean draws the connection between female heroine and writer, arguing that "both Lafayette's authorial strategy and the controversial conduct she devises for her heroine are attempts to avoid the loss of 
When Nemours first appears in the room, "Elle rougit, et essaya de cacher sa rougeur" (300). ${ }^{43}$ When she leaves, her uncle the Vidame "la vit si troublée qu'il n'osa lui parler" (309). ${ }^{44}$ Later that evening, "Mme de Clèves n'était pas en état d'en trouver [repos]; ce lui était une chose si nouvelle d'être sortie de cette contrainte qu'elle s'était imposée. . . . Elle fut étonnée de ce qu'elle avait fait; elle s'en repentit; elle en eut de la joie: tous ses sentiments étaient pleins de trouble et de passion" $(310) .{ }^{45}$ It is difficult to capture the complexity of the systems at work here. On the one hand, the princess appears as a young lady who has worked hard to make up her mind about Nemours, choosing not to be with him despite the dissipation of all societal obstacles. Many scholars have lingered on this point, ${ }^{46}$ commenting on her strength of mind in knowing that she would never be happy with Nemours, thus deciding to sacrifice everything "à un devoir qui ne subsiste que dans [son] imagination" (309). ${ }^{47}$ On the other hand, and as many others have argued, the princess shows weakness of character by not giving her relationship with Nemours, which is clearly meant to be, a chance, and instead choosing to withdraw and fade quietly. ${ }^{48}$

authority that accompanies every public appropriation of fictionalized female desire. ... Both author and character forge an écriture feminine that is beyond person but not beyond gender" (887).

43. "She blushed, and tried to hide her blushes" (100).

44. "Saw her so agitated that he did not dare to speak to her" (105).

45. "He was in no condition to find rest; it was for her such a new thing to lay aside the reserve which she had imposed upon herself; ... She was amazed at what she had done, and repented it bitterly; she was also made happy by it,- she was completely upset by love and agitation" (105-6).

46. See, for example, Alliston, who believes that the princess is "able to make her mother's precept triumph over the 'real"' (55). DeJean writes that "Lafayette's heroine learns that, to gain authority she must fashion herself according to a female script" (896-97). DeJean sees the princess's encounter with Nemours during the second aveu as a sign of strength, rather than weakness. Michael Koppisch claims that the princess's individuality comes from "her will to preserve for herself an ordered life free from passions' disruptive reign" (207).

47. "to a duty which exists only in [her] imagination" (135).

48. See, for example, Peggy Kamuf's chapter in Fictions of Feminine Desire, in which she uses the first meeting between Monsieur de Clèves and the princess in the jewelry shop, and the subsequent symbolization of the princess as a jewel, as a starting point to analyze the princess's education as symbolic castration by her mother (and, later, by her substitute, $M$. de Clèves). Kamuf reads the ending of the novel in this light, focusing on the fact that her death "sustains and consolidates the construction of an unattainable, inimitable model. In its stead, the unmatched force of the heroine's desire ... expires without a trace" (96). Domna Stanton reads the end of the text as a reflection of the fact that in seventeenth-century usage, repos was both a "profound ethical 
Both readings, while valid, miss a crucial point: the princess is still attempting the impossible, to balance both modes of discourse. ${ }^{49}$ The princess reveals her feelings to Nemours, but the courtly voice of sprezzatura reminds her this is dangerous behavior; she blushes at the same time as she tries to hide her blushes. ${ }^{50}$ The agitation she feels at the end of their encounter reveals a deeply troubled interior, an interior torn between duty and passion, between exposing and concealing. The words she speaks illuminate her decision regarding Nemours, and they show readers the path of where she has been and where she plans to go. As Stephanie Merrim writes, the princess must

constantly shuttle back and forth between self-control and containment, and explosion or "decontainment," all the while straining to assert lucidity and self-vigilance. This struggle within the Princess is, of course, the very core of the novel. $(123)^{51}$

It is true that the princess is almost perpetually engaged with the struggle between the models of "containment" and "lucidity." In the text's concluding pages, one might assume she has reached some kind of balance in her resolution and subsequent withdrawal. Yet, the involuntary confessions of the flesh that accompany her words during and after the second aveu show us a young lady still troubled by passions, still learning from her slips, still reflecting on how she might reconcile two conflicting desires.

concept and, at the same time, a commonplace" (80). She notes LaFayette's refusal to tell readers whether the princess's feelings for Nemours actually disappear with time, but highlights the heroine's success in attaining "la mort des désirs" (96).

49. Some scholars hold the middle ground; for example, Marie-Odile Sweetser believes that the princess's selfhood lies in a self-consciousness of the things that set her apart from other members of court (222).

50. In "A Modest Proposal for Queering the Past," Pierre Zoberman uses the princess's behavior in the final scene with Nemours to draw a distinction between the early modern gay and queer. He defines the latter as "the calling into question of traditional, heteronormative definitions of gender roles in various historical contexts" (35). The princess, he writes, reverses gender roles by saying all the things Nemours should say and do and none of the things that a woman should (44). Calling her a "Cartesian in hiding" (43), Zoberman sees the second aveu as the moment in which the princess "carv[es] out a space of her own, a paradoxical space, distinct from both archetypal feminine spaces at the time, [finding] queer lodgings to end her story and her life" (47). 51 . In her own brilliant investigation of early modern women writers, Merrim analyzes the many perspectives (130-31) and concludes that the princess's experience in the text resembles the structure of a bildungsroman, complete with a sense of self-fulfillment. The various societal challenges the princess faces force her to "forge her conscience on her own terms," resulting in a character who, in the end, emerges with "emotional depth" $(122,123)$. 
Refusing Nemours does not result in or come from a self that is unaffected by passions. It does not create a Cartesian or courtly sense of mastery. The princess admits to herself that her desire to create a certain self-image is built on a devoir that exists only as one to herself. In this sense, the princess separates herself from the actions and reactions prescribed by courtly behavior. On the other hand, however, she bases this self-proposed devoir on her reaction to the letter and on the examples of other women. She predicts that Nemours will be unfaithful, and realizes that she does not want to feel jealously "commes les autres femmes." Her decision and behavior are at the same time deeply psychological-she separates herself from the devoirs of court-and a subject deeply torn between the modes of confession and court. She builds her singular self-revelation about her future feelings on the behavioral models she has observed and, at many moments, participated in. None of these interior layers culminate in a coherent whole. Lafayette's text mirrors its own heroine, shuffling between systems of control to carefully construct an ephemeral, singular, illusionary representation. The princess confesses to and conceals from Nemours. She withdraws to a convent-a confessional space-but only for half the year. Any kind of definitive reading is masked by the inherent duplicities of the two codes at work within the text itself. Only involuntary confessions of the flesh, in their silent exposure, offer deeper insights into the dual systems at work. If these slips do not reveal a well-formed self, they are nonetheless distilled signs of truth, unmarred by the competing codes of courtliness and confession. Involuntary confessions of the flesh trouble the seventeenth-century modes of thinking in every way-they disrupt the civilizing process and thicken the already complex structure of confession. Nonetheless, they provide the reader with unique insight into what goes on behind the scenes of either mode; as essentially incapable of illusion or dissimulation, they trigger more than just a codifiable reading of the passions. Both products of and participants in the modes of confession and dissimulation, involuntary confessions of the flesh create the reflection and knowledge necessary to function within a highly stylized, highly judgmental culture and provide the keys to building the nascent self.

University of Nebraska, Lincoln

\section{Works Cited}

Alliston, April. "What the Princess Left; or, Exemplary Faults in La Princesse de Clèves." Virtue's Faults: Correspondences in Eighteenth-Century British and French Women's Fiction. Stanford: Stanford UP, 1996. 33-76.

Bates, Catherine. "Literature and the Court." The Cambridge History of Early Modern English Literature. Ed. David Loewenstein and Janel Mueller. Cambridge: Cambridge UP, 2002. 343-73. 
Beasley, Faith. Revising Memory: Women's Fiction and Memoirs in Seventeenth Century France. New Brunswick: Rutgers UP, 1990.

Bénichou, Paul. Les Morales du Grand Siècle. Paris: Gallimard, 1948.

Berger, Harry, Jr. "Sprezzatura and the Absence of Grace." The Book of the Courtier. Ed. Daniel Javitch. New York: Norton, 2002. Reprinted by permission from The Absence of Grace: Spezzatura and Suspicion in Two Renaissance Courtesy Books Stanford: Stanford UP, 2000). 294-307.

Brooks, Peter. Troubling Confessions: Speaking Guilt in Law and Literature. Chicago: U of Chicago P, 2000.

Bryson, Anna. From Courtesy to Civility: Changing Codes of Conduct in Early Modern England. Oxford: Clarendon, 1998.

Castiglione, Baldassare. The Book of the Courtier. Trans. Charles S. Singleton. Ed. Daniel Javitch. New York: Norton, 2002.

Coulet, Henri. Le Roman jusqu’à la révolution. Paris: A. Colin, 1967-68.

DeJean, Joan. "Lafayette's Ellipses: The Privileges of Anonymity." PMLA 99.5 (1984): 884-902.

Descartes, René. Les Passions de L'Ame. 1649. Ed. Geneviève Rodis-Lewis. Paris: Librairie Philosophique, 1955.

DiPiero, Thomas. Dangerous Truths and Criminal Passions: The Evolution of the French Novel, 1569-1791. Stanford: Stanford UP, 1992.

Elias, Norbert. The Civilizing Process: Sociogenetic and Psychogenetic Investigations. 1939. Ed. Eric Dunning, Johan Goudsblom and Stephen Mennell. Trans. Edmund Jephcott. Malden: Blackwell, 1994.

. The Court Society. Trans. Edmund Jephcott. Oxford, UK: Basil Blackwell, 1983.

Faret, Nicholas. L'bonneste homme, ou, L'art de plaire à la court. 1630. Ed. M. Magendie. Paris : Presses Universitaires de France, 1925. ARTFL 1996. 22 June 2011.

. The honest man: or, The art to please in court. Trans. E. G. London: Harper, 1632. EEBO. British Library. 22 June 2011.

Foucault, Michel. Histoire de la Sexualité I: La volonté de savoir. N.p.: Gallimard, 1976.

. The History of Sexuality I: An Introduction. Trans. Robert Hurley. New York: Random House, 1978.

Greenblatt, Stephen. Renaissance Self-Fashioning: From More to Shakespeare. 2nd ed. Chicago: U of Chicago P, 2005.

Horowitz, Louise K. "Madame de Lafayette." Love and Language: A Study of the Classical French Moralist Writers. Columbus: Ohio State UP, 1977. 51-72.

Kamuf, Peggy. "A Mother's Will: The Princess de Clèves." Fictions of Feminine Desire. Lincoln: U of Nebraska P, 1982. 67-96. 
Koppisch, Michael S. "The Princesse de Clèves's Will to Order." An Inimitable Example: The Case for the Princesse de Clèves. Ed. Patrick Henry. Washington, D.C.: Catholic U of America P, 1992. 195-208.

Lafayette, Madame de. La Princesse de Clèves. Paris: Seuil, 1992.

. The Princess of Cleves. Ed. John D. Lyons. New York: Norton, 1994.

Lamy, Bernard. La rhétorique, ou, l'Art de Parler (1675). Ed. Michel Meyer and B. Timmermans. Paris: Presses universitaires de Paris, 1998.

Liu, Catherine. "From Faux Pas to Faut Pas, or on the Way to The Princess of Cleves." Tulsa Studies in Women's Literature 17.1 (1998): 123-44.

Lyons, John D. Before Imagination: Embodied Thought from Montaigne to Rousseau. Stanford: Stanford UP, 2005.

Malebranche, Nicolas. De la recherche de la vérité, où l'on traite de la nature de l'esprit de l'homme, et de l'usage qu'il, en doit faire pour éviter l'erreur des sciences. 1721. Ed. Geneviève Rodis-Lewis. Paris: J. Vrin, 1945.

Marin, Louis. Le Portrait du Roi. Paris: Éditions de Paris, 1981.

Merrim, Stephanie. Early Modern Women's Writing and Sor Juana Inés de la Cruz. Nashville: Vanderbilt UP, 1999.

Miller, Nancy K. "Emphasis Added: Plots and Plausibilities in Women's Fiction." PMLA 96.1 (1981): 36-48.

Moriarty, Michael. "Identification and the Boundaries of the Self in EarlyModern Thought." Nottingham French Studies 47.3 (2008): 24-33.

Spinoza, Benedict de. Ethics. Ed., introd. James Gutmann. New York: Hafner, 1949.

Stanton, Domna. "The Ideal of 'Repos' in Seventeenth-Century French Literature." L'Esprit Créateur 15 (1975): 79-104.

Sweetser, Marie-Odile. "In Search of Selfhood: The Itinerary of the Princesse de Clèves." An Inimitable Example: The Case for the Princesse de Clèves. Ed. Patrick Henry. Washington, D.C.: Catholic U of America P, 1992. 209-224.

Wimmers, Inge Crosman. "Rewriting Vraisemblance in La Princesse de Clèves." Poetics of Reading: Approaches to the Novel. Princeton: Princeton UP, 1988. 24-55.

Zoberman, Pierre. "A Modest Proposal for Queering the Past." Queer Sexualities in French and Francophone Literature and Film. Ed. James Day. Kenilworth: Rodopi, 2007. 35-47. 